\title{
Parameter Bakteremia pada Anak dengan Keganasan dan Demam Neutropenia
}

\section{Parameters Bacteremia n Children with Malignancy and Febrile Neutropenia}

\author{
Susanto Nugroho \\ Laboratorium IImu Kesehatan Anak Rumah Sakit Umum Dr. Saiful Anwar Malang
}

\begin{abstract}
ABSTRAK
Demam netropenia merupakan komplikasi yang serius dan sering pada anak dengan keganasan dan dapat mengancam nyawa. Meskipun demikian bukti menunjukkan bahwa infeksi lokal maupun sistemik ditemukan pada 48-60\% dari episode demam netropenia namun hanya16-20\% diantaranya mengalami bakteremia. Bakteremia merupakan baku emas diagnosis infeksi bakteri yang mempengaruhi prognosis dan dapat meningkatkan resiko kematian. Studi cross-sectional ini dilakukan in bangsal Hematologi-Onkologi Anak RS dr. Saiful Anwar untuk mengidentifikasi gejala dan gambaran klinis infeksi serta parapmeter bakteremia pada anak dengan keganasan dan febrile netropenia. Subjek penelitian melibatan 68 pasien anak dengan keganasan dan demam netropenia yang dirawat di rumah sakit dan mendapatkan kemoterapi. Parameter bakteremia yang dianalisis terdiri dari infeksi klinis, suhu tubuh saat episode demam netropenia, jumlah lekosit, neutrofil, monosit dan fagosit absolut. Secara klinis 65 dari 68(95.5\%) mengalami infeksi tetapi bakteremia hanya ditemukan pada 14 dari 68 kultur darah pasien(20,6\%). Infeksi klinis yang terkait dengan baktermia adalah infeksi saluran pernafasan akut non pneumonia ( $p=0.047$; OR=3.7; $\mathrm{Cl} 95 \%$ 0,96-14,40). Parameter klinis yang terbukti berhubungan dengan bakteremia adalah jumlah netrofil absolute $(p=0,003)$ dan fagosit absolut $(p=0,013)$. Dapat disimpulkan bahwa infeksi saluran pernafasan akut non pnemoni, jumlah netrofil dan fagosit absolut dapat digunakan sebagai parameter klinis bakteremia pada anak dengan keganasan dan demam netropenia.
\end{abstract}

Kata Kunci : Anak, bakteremia, demam netropenia, keganasan

\begin{abstract}
Febrile neutropenia is a serious and common complication in children with malignancy, and it is potentially life threatening. However, the evidence demonstrated that the local or systemic clinical infections were found in approximately $48-60 \%$ of febrile neutropenia episodes, but only 16-20\% with bacteremia. Bacteremia is a gold standard diagnostic for bacterial infection that influence the prognosis, and can increase the risk of death. This cross-sectional analytic study was conducted at Pediatric Hematology Oncology ward Dr. Saiful Anwar General Hospital to determine clinical signs and symptoms of infection, and parameters associated with bacteremia in children with malignancy and febrile neutropenia. Subjects were 68 childhood patients with malignancy and febrile neutropenia were hospitalized and administered chemotherapy. The parameters associated with bacteremia were analyzed, such as the clinical infection, the body temperature at febrile neutropenia episode, leucocyte count, absolute neutrophil count, absolute monocyte count and absolute phagocyte count. However, clinically 65 from 68 patients (95,5\%) suffered infection, but bacteremia were found in 14 from 68 blood culture of patients $(20,6 \%)$. The clinical infection associated with bacteremia is non-pneumonia acute respiratory tract infection with $p=0,047(O R=3,7 ; C l 95 \% 0,96-14,40)$. While, the clinical parameters associated with bacteremia are absolute neutrophil count $(p=0,003)$ and absolute phagocyte count $(p=0,013)$. It can be concluded that non-pneumonia acute repiratory tract infection, absolute neutrophil count and absolute phagocyte count associated with bacteremia in children with malignancy and febrile neutropenia.
\end{abstract}

Keywords : Bacteremia, children with malignancy, febrile neutropenia

Jurnal Kedokteran Brawijaya, Vol. 26, No. 2, Agustus 2010; Korespondensi: Susanto Nugroho. Laboratorium Ilmu Kesehatan Anak Rumah Sakit Umum Dr. Saiful Anwar Malang, Jl. Jaksa Agung Suprapto No. 2 Malang Telp. (0341) 343343 Email: susantonugroho.ns@gmail.com 


\section{PENDAHULUAN}

Demam neutropenia didefinisikan sebagai suhu tubuh $380 C$ atau lebih pada keadaan pasien dengan neutropenia (hitung neutrofil absolut $<500 \mathrm{sel} / \mu \mathrm{L}$ ) $(1,2)$. Demam neutropenia adalah komplikasi yang serius dan sering ditemukan pada anak dengan keganasan terutama yang mendapatkan kemoterapi (3). Dalam keadaan neutropenia, infeksi bakterial dapat timbul dan berkembang sangat cepat, dan merupakan kegawatdaruratan yang berpotensi mengancam jiwa. Apabila tidak segera didiagnosis dan mendapatkan terapi, pasien dapat meninggal karena infeksi bakterial sistemik atau sepsis berat (2-4).

Bukti klinik dari penelitian sebelumnya menunjukkan bahwa pada sekitar 48-60\% episode demam neutropenia didapatkan infeksi lokal maupun sistemik secara klinis dan adanya keterlibatan infeksi bakterial. Hanya 16-20\% diantaranya yang terbukti ditemukan bakteri pada biakan darah (bakteremia) (5). Bakteremia merupakan baku emas untuk membuktikan adanya infeksi bakterial. Spektrum klinis infeksi dan risiko adanya bakteremia pada demam neutropenia sangat bervariasi, namun bukti adanya bakteremia menentukan derajat keparahan penyakit yang sangat berpengaruh terhadap prognosis (46).

Beberapa penelitian sebelumnya telah melaporkan berbagai parameter yang dapat digunakan untuk mengidentifikasi kejadian bakteremia pada anak dengan penyakit keganasan dan demam neutropenia. Parameter tersebut antara lain: suhu tubuh saat timbul neutropenia, jumlah leukosit, hitung neutrofil absolut, hitung monosit absolut dan hitung fagosit absolut $(6,7,8)$. Karakteristik pasien anak dengan keganasan dan demam neutropenia yang berhubungan secara bermakna dengan morbiditas dan mortalitas akibat infeksi bakterial adalah ras, jenis keganasan, kelompok umur dan komplikasi yang terjadi $(9,10)$. Dalam publikasinya, Macartney G (2007), melaporkan bahwa parameter yang memiliki hubungan secara bermakna dengan kejadian bakteremia adalah hitung neutrofil dan hitung monosit absolut (6). Sedangkan hasil penelitian Oguz A (2006) dan Corapcioglu (2006) menunjukkan bahwa hitung neutrofil absolut merupakan satu-satunya parameter yang memiliki hubungan secara bermakna dengan kejadian bakteremia $(8,11)$.

Terapi empirik dengan kombinasi antibiotika 8-laktam spektrum luas dan amikasin merupakan terapi standar untuk infeksi pada keadaan demam neutropenia karena memiliki efek sinergistik untuk bakteri gram-negatif dan mencegah resistensi $(12,13)$. Pada saat timbul demam neutropenia dan didapatkan gejala dan tanda klinis infeksi, identifikasi adanya bakteremia akan membantu untuk menentukan regimen antibiotika selanjutnya $(13,14)$.

Penelitian ini dilakukan dengan tujuan untuk mengetahui secara klinis gejala dan tanda infeksi yang timbul, serta menentukan parameter yang terkait dengan kejadian bakteremia pada pasien anak dengan keganasan yang mengalami demam neutropenia.

\section{METODE}

Penelitian ini merupakan studi analitik dengan metode cross sectional yang dilakukan selama bulan Februari 2007 sampai dengan Juli 2008. Subjek dalam penelitian ini adalah semua pasien anak dengan penyakit keganasan yang sedang dirawat dan mendapatkan kemoterapi di bangsal Hematologi-Onkologi Anak RSU Dr. Saiful Anwar yang mengalami episode demam neutropenia. Setiap pasien dapat mengalami lebih dari satu episode demam neutropenia. Pasien dinyatakan mengalami demam neutropenia apabila didapatkan suhu tubuh $>380 \mathrm{C}$ dan keadaan neutropenia (hitung neutrofil absolut $<500$ sel $/ \mu \mathrm{L})$.

Pada saat inklusi atau evaluasi pertama kali, dilakukan pemeriksaan fisik dan laboratorium serta kultur darah. Diagnosis keganasan ditentukan berdasarkan standar pemeriksaan diagnostik sesuai dengan jenis keganasannya (misalnya: aspirasi sumsum tulang, CT scan, MRI atau penanda tumor).

Pemeriksaan dan penghitungan beberapa parameter klinis maupun hematologis yang dilakukan adalah suhu tubuh saat episode demam, hitung leukosit, hitung neutrofil absolut, hitung monosit absolut, dan hitung fagosit absolut. Hitung neutrofil absolut dihitung dari persentase neutrofil polimorfonuklear dan bentuk band dikalikan dengan jumlah leukosit. Hitung monosit absolut didapat dari hasil perkalian persentase monosit dan jumlah leukosit total, sedangkan hitung fagosit absolut merupakan jumlah hitung neutrofil dan monosit absolut.

Baku emas untuk menunjukkan adanya infeksi bakterial ditentukan dengan adanya pertumbuhan kuman pada kultur darah atau bakteremia. Kultur darah yang dilakukan dalam penelitian ini menggunakan teknik pemeriksaan kualitatif dengan metode Bactec untuk mengurangi bias pada hasil akibat pemberian antibiotika sebelumnya, meskipun pengambilan darah untuk kultur dilakukan sebelum dimulai pemberian antibiotika.

Data yang terkumpul dianalisis dengan t-test dan ChiSquare test menggunakan SPSS 13.0 untuk menentukan parameter klinik dan laboratorium bakteremia.

\section{HASIL}

Selama periode penelitian didapatkan 68 episode demam neutropenia pada pasien anak dengan penyakit keganasan yang sedang dirawat di bangsal Hematologi-Onkologi Anak RSU Dr. Saiful Anwar Malang, yang seluruhnya diikutkan dalam penelitian ini. Tiga pasien mengalami 2 episode dan seorang pasien mengalami 3 episode demam neutropenia.

Umur rata-rata subjek penelitian adalah 5,6 tahun $\pm 2,1$ tahun dengan sebaran menurut jenis kelamin laki-laki dan perempuan yang hampir sama. Seluruh pasien mendapatkan tindakan invasif berupa pemasangan kateter intravena, dan hanya $5,9 \%-10,3 \%$ pasien yang menggunakan kateter urin, nasal, nasogastrik maupun orogastrik. Penggunaan granuloyte-colony stimulating factor (G-CSF) sangat terbatas, diberikan pada 4 dari 68 pasien $(5,9 \%)$ yang mengalami neutropenia berat (hitung neutrofil absolut $<100 / \mu \mathrm{L})$. Berdasarkan jenis keganasan, sebanyak 54 dari 68 pasien $(79,4 \%)$ adalah keganasan hematologi berupa leukemia limfoblastik akut, leukemia myeloid akut maupun leukemia myeloid kronik.

Hasil analisis statistik untuk infeksi klinis yang terkait dengan kejadian bakteremia dengan chi-square test menunjukkan bahwa hanya infeksi saluran pernafasan akut (ISPA) non-pneumonia yang memiliki hubungan 
secara bermakna dengan kejadian bakteremia $(p=0,047$; OR=3,7; Cl 95\% 0,96-14,40) (Tabel 1).

Tabel 1. Uji Chi-square infeksi klinis dengan kejadian bakteremia

\begin{tabular}{lcccccc}
\hline & \multicolumn{2}{c}{ Bakteremia } & & & \\
\cline { 2 - 3 } No Infeksi Klinis & $\begin{array}{c}\text { Negatif } \\
(\mathrm{n}=54)\end{array}$ & $\begin{array}{c}\text { Positif } \\
(\mathrm{n}=14)\end{array}$ & Nilai $\mathrm{p}$ & OR & Ci95\% \\
\hline 1 ISPA non-pneumonia & $7 / 54$ & $5 / 14$ & 0,047 & 3,7 & $0,96-14,40$ \\
2 ISPA pneumonia & $5 / 54$ & $3 / 14$ & 0,208 & 2,6 & $0,55-12,89$ \\
3 Gastroenteritis & $9 / 54$ & $2 / 14$ & 0,829 & 0,8 & $0,15-4,37$ \\
4 Selulitis & $3 / 54$ & $2 / 14$ & 0,265 & 2,8 & $0,42-18,87$ \\
5 Infeksi saluran kemih & $4 / 54$ & $2 / 14$ & 0,419 & 2,0 & $0,34-12,73$ \\
6 Mucositis & $15 / 54$ & $4 / 14$ & 0,953 & 1,0 & $0,28-3,82$ \\
7 Sepsis & $2 / 54$ & $2 / 14$ & 0,134 & 4,3 & $0,55-33,93$
\end{tabular}

Keterangan:*terdapat hubungan yang

bermakna apabila nilai $\mathrm{p}<0,05$

Analisis univariat untuk parameter klinik dan laboratorium terhadap kejadian bakteremia menunjukkan bahwa parameter yang memiliki hubungan secara bermakna dengan kejadian bakteremia adalah hitung neutrofil absolut $(p=0,003)$ dan hitung fagosit absolut $(p=0,013)$ (Tabel 2).

Tabel2. Uji $t$ parameter klinik dengan kejadian bakteremia

\begin{tabular}{llccc}
\hline & & \multicolumn{2}{c}{ Bakteremia } & \\
\cline { 3 - 4 } No & Parameter Klinik & $\begin{array}{c}\text { Negatif } \\
(\mathrm{n}=54)\end{array}$ & $\begin{array}{c}\text { Positif } \\
(\mathrm{n}=14)\end{array}$ & $p^{*}$ \\
\hline 1 & Suhu Tubuh $\left({ }^{\circ} \mathrm{C}\right)$ saat inklusi & $38,8 \pm 0,6$ & $39,0 \pm 0,6$ & 0,272 \\
2 & Jumlah keukosit (/uL) & $4900 \pm 2400$ & $3746 \pm 2375$ & 0,057 \\
3 & Hitung neutrofil absolute (/uL) & $389 \pm 68$ & $320 \pm 122$ & $0,003^{*}$ \\
4 & Hitung monosit absolute (/uL) & $423 \pm 209$ & $329 \pm 232$ & 0,075 \\
5 & Hitung fagosit absolute (/uL) & $812 \pm 211$ & $650 \pm 323$ & $0,013^{*}$ \\
\hline
\end{tabular}

Keterangan: *terdapat hubungan yang

bermakna apabila nilai $p<0,05$

\section{DISKUSI}

Dari 68 pasien yang menjadi subjek dalam penelitian ini, ditemukan infeksi lokal maupun sistemik secara klinis pada 65 pasien $(95,5 \%)$. Infeksi klinis yang terbanyak ditemukan adalah mucositis $(27,9 \%)$, ISPA nonpneumonia $(17,6 \%)$ dan gastroenteritis $(16,2 \%)$. Meskipun didapatkan infeksi secara klinis, namun tidak terbukti terjadi leukopenia dimana jumlah leukosit ratarata adalah $4662(S D \pm 423) / \mu \mathrm{L}$. Dibandingkan dengan hasil penelitian sebelumnya yang menunjukkan bahwa infeksi klinis ditemukan pada 48-60\% pasien keganasan dengan demam neutropenia, pada penelitian didapatkan angka kejadian yang lebih tinggi (5). Insiden infeksi klinis yang tinggi kemungkinan disebabkan karena pasien tidak dirawat di ruang isolasi khusus, mengingat bahwa pasien dalam keadaan immunocompromize berat karena penyakit keganasan dan neutropenianya.
Hasil analisis chi-square test menunjukkan bahwa dari berbagai infeksi klinis tersebut yang terbukti memiliki hubungan secara bermakna kejadian bakteremia adalah ISPA non-pneumonia hal ini. Berbeda dengan hasil penelitian lainnya yang menunjukkan bahwa pneumonia dan sepsis merupakan infeksi klinis yang berhubungan secara bermakna dengan kejadian bakteremia, dan meningkatkan angka kematian $(9,10)$. Secara bakteriologik, dari pemeriksaan kultur darah ditemukan pertumbuhan bakteri (bakteremia) pada 14 dari 68 pasien $(20,6 \%)$. Data ini menunjukkan angka yang sedikit lebih tinggi dibandingkan pada penelitian-penelitian sebelumnya yang menemukan $16-20 \%$ bakteremia pada kondisi yang sama $(4,5)$.

Dari data ini dapat diketahui bahwa meskipun infeksi yang secara klinis ditemukan pada anak dengan keganasan dan demam neutropenia berkaitan dengan infeksi bakterial, namun hanya sebagian kecil yang terbukti secara bakteriologik. Angka kejadian bakteremia yang rendah menyebabkan terapi antibiotika secara empirik menjadi sangat penting dalam tata laksana awal pasien, meskipun bukti adanya bakteremia akan sangat membantu dalam menentukan terapi antibiotika selanjutnya $(12,13,14)$.

Dalam hubungannya dengan kejadian bakteremia, beberapa parameter yang diuji menunjukkan hubungan yang tidak bermakna. Dari hasil analisis menggunakan $t$ test, parameter yang terbukti memiliki hubungan secara bermakna dengan kejadian bakteremia adalah hitung neutrofil absolut $(p=0,003)$ dan hitung fagosit absolut $(p=$ 0,013 ). Parameter lainnya yaitu suhu tubuh, jumlah leukosit, dan hitung monosit absolut tidak memiliki hubungan secara bermakna. Seperti hasil beberapa penelitian lainnya, suhu tubuh dan jumlah leukosit tidak memiliki hubungan secara bermakna dengan kejadian bakteremia $(6,8,9,10)$. Kemungkinan hal ini disebabkan karena pemberian antibiotika profilaksis selama kemoterapi yang dapat berpengaruh terhadap derajat infeksi (6,8-10).

Hasil penelitian yang berbeda ditunjukkan oleh Basu dkk (2005), yang melaporkan bahwa parameter yang memiliki hubungan secara bermakna dengan kejadian bakteremia adalah hitung neutrofil dan hitung monosit absolut (9). Sedangkan hasil penelitian Oguz (2006) dan Corapcioglu (2006) menunjukkan bahwa hitung neutrofil absolut merupakan satu-satunya parameter yang memiliki hubungan secara bermakna dengan kejadian bakteremia $(8,11)$. Perbedaan ini menunjukkan bahwa parameterparameter yang terkait dengan kejadian bakteremia pada anak dengan keganasan dan demam neutropenia harus dianalisis secara menyeluruh dengan memperhatikan klinis infeksi yang ditemukan.

Dari semua infeksi klinis yang ditemukan pada anak dengan keganasan dan demam neutropenia, yang terbukti berkaitan secara bermakna dengan kejadian bakteremia adalah infeksi saluran pernafasan akut (ISPA) nonpneumonia 95\%. Parameter yang terkait secara bermakna dengan kejadian bakteremia pada anak dengan keganasan dan demam neutropenia adalah hitung neutrofil absolut dan hitung fagosit absolut. 


\section{DAFTAR KEPUSTAKAAN}

1. Koh AY and Pizzo PA. Infectious Diseases in Pediatric Cancer. In: Orkin SH, Fisher DE, Look AT (Eds). Oncology of Infancy and Childhood 1st edition. Philadelphia:Saunders Elsevier; 2009: 1099-1120

2. Meckler G and Lindemulder S. Fever and Neutropenia in Pediatric Patients with Cancer. Emergency Medicine Clinics of North America. 2009; 27: 525-544.

3. Paganini HR, Aguirre C, Puppa G, et al. A Prospective, Multicentric Scoring System to Predict Mortality in Febrile Neutropenic Children with Cancer. Cancer. 2007; 109(12): 2572-2579.

4. Viscoli C, Varnier O, and Marchetti M. Infection in patients with febrile neutropenia: Epidemiology, microbiology, and risk stratification. Clinical Infectious Diseases. 2005; 40: S240-245.

5. Miedema KGE, Bont ESJM, Nijhuis CSMO, Vliet VD, Kamps WA, and Tissing WJE. Validation of a New Risk Assessment Model for Predicting Adverse Events in Children With Fever and Predicting Adverse Events in Children wth Fever and Chemotherapy-Induced Neutropenia. Journal of Clinical Oncology. 2011; 29(7): 182-184.

6. Macartney G, Zvonar R, McDiarmid S, Harris BE, and Laplante J. Risk Stratification and Febrile Neutropenia the Ottawa Experience. Oncology Exchange. 2007; $6(3): 43-47$

7. Lal A, Bhurgri Y, Rizvi N, et al. Factors Influencing Inhospital Length of Stay and Mortality in Cancer Patients Suffering from Febrile Neutropenia. Asian Pacific Journal of Cancer Prevention. 2008; 9: 303308.
8. Oguz A, Karadeniz C, and Citak EC. Which One is a Risk Factor for Chemotherapy-Induced Febrile Neutropenia in Childhood Solid Tumors: Early Lymphopenia or Monocytopenia. Pediatric Hematology Oncology. 2006; 23(2): 143-151.

9. Basu SK, Fernandez ID, Fisher SG, Asselin BL, and Lyman GH. Length of Stay and Mortality Associated With Febrile Neutropenia Among Children With Cancer. Journal of Clinical Oncology. 2005; 23(32): 7958-7966.

10. Lalami Y, Paesmans M, Muanza F, et al. Can We Predict the Duration of Chemotherapy-Induced Neutropenia in Febrile Neutropenic Patients, Focusing on RegimenSpecific Risk Factors A Retrospective Analysis. Annals of Oncology. 2006; 17(2): 507-514.

11. Corapcioglu F, Sarper N, and Zengin E. Monotherapy with Piperacillin/Tazobactam Versus Cefepime as Empirical Therapy for Febrile Neutropenia in Pediatric Cancer Patients: A Randomized Comparison. Journal of Pediatric Hematology/Oncology. 2006; 23(3): 177186.

12. Nijhuis CO, Kamps WA, Daenen SM, et al. Feasibility of Withholding Antibiotics in Selected Febrile Neutropenic Cancer Patients. Journal of Clinical Oncolology. 2005; 23(30): 7437-7444.

13. Laoprasopwattana K, Pruekprasert P, Laosombat V, and Wongchanchailert M. Clinical Outcome of Febrile Neutropenia in Children with Cancer Using Ceftazidime and Aminoglycosides. Journal of Pediatric Hematology/Oncology. 2007; 24: 595-606.

14. Kannangara S. Management of Febrile Neutropenia. Community Oncology. 2006; 3: 585-591. 